\title{
Internalization of Local Wisdom Values through Music Art as Stimulation of Strengthening Character Education in Early Childhood Education; A Hermeneutic Analysis and Ethnography Studies
}

\author{
Desyandri \\ Universitas Negeri Padang \\ Padang, Indonesia \\ desyandri@fip.unp.ac.id
}

\begin{abstract}
This article aims to describe the role of teachers of Early Childhood Education in the process of understanding and internalizing the values of local Minangkabau wisdom contained in the song "Kampuang nan Jauah di Mato" as stimulation in early childhood to strengthen the nation's character education. This article is the result of conceptual analysis and synthesis of various literatures. The research findings that internalization the educational values of Minang song through: (1) appreciating the Minang song; (2) the practice of imitating the song (3) expressing themselves by singing the song, (4) identifying and knowing the meaning of the important words contained in lyrics, and (5) implementations the meaning of songs through actions and behaviors that reflect Minangkabau characters.
\end{abstract}

Keywords--appreciation; imitation; expression; music; minang song

\section{INTRODUCTION}

The learning process of Early Childhood Education (PAUD) should act as a driver of success of children in the next education level. Implementation of learning in early childhood adheres to the principle of playing while learning. Various areas of development are taught by integrating into a whole program of learning activities. To support the program can be done with art activities. One type of art is the art of music. The experience of music art is the primary means to communicate an understanding of themselves and their world.

Music and singing activities are an important part of early childhood education programs. Froebel a prominent figure of Kindergarten believes in the values of musical experience for children (Bayless in Jatmiko, 1996). It is recommended that young children should be given as much singing and play experience as possible[1]. The role of music on behavioral aspects. Music can train the fineness of hearing, which brings the smoothness of feels and mind, the practice becomes the balance of language practice, both can not be separated from each other[2]. Furthermore, the art of music has an important role in the life of a learner. Learners who participate in music art activities, in addition to developing creativity, music can also fostering individual development, developing the sensitivity, build a sense of beauty, revealed the expression, challenge, train discipline and introduce learners to their nation's cultural history. Music is also a tool to enhance and foster personal abilities. Personal development includes aspects of intellectual, creativity, reading, language, behavior, and social interaction competence[3].

Music art is one element of culture. The position of art in the culture that art throughout the world is always used as a measure to establish the low culture of a nation, so many people think that culture is art, and art is culture[2]. In addition, the art of culture is the culmination of the civilization of a nation in which embodied ethics, norms, and moral adopted, so that the formation of morals can be done with the activities of art[4].

The cultural interrelationship with the art of music is also described more deeply that: (a) music is part of the cultural heritage. An important part is the transmission of knowledge and skills that embrace cultural values from one generation to the next. The process of inheriting cultural values refers to the best of the past to gain perspective on the present and the possibility of projecting the future; (b) music is socially determined by cultural differences among human groups and knowledge of various values; (c) music functions for the development of personality. Music takes place in human life as a powerful tool for adaptation and evolution. This means that music provides a sensitivity between individuals and society, tradition and innovation, biological replication and evolutionary development, and is sensitive to self-awareness and consciousness outside of the human self[5].

Explanation of some opinions about the interplay of music art with the culture described earlier, confirmed that the art of music has a close relationship with the culture. Music as a cultural product is a means to internalize and manifest the values contained in a culture, as well as to process the inheritance and transformation of cultural values from one generation to another. Thus, the interplay of the art of music with culture is a means to cultivate perceptions of past, present, and the ability to project the future. Positive cultural values that existed in the past can be preserved and functioned 
as a means to live the present life, so it can be a consideration for projecting the future.

Cultural values functioned as educational guidelines and tools in bring up to actions and behavior of commendable behavior in the present and the basis of consideration to project actions and commendable behavior of the future, so that cultural values are very useful for strengthening individual characters and society. The importance of cultural values as an educative means can give meaning that these values contain the values of wisdom that help human beings in organizing, conduct, and living life in family and society.

The caracterstics of local wisdom can be explained as follows: local wisdom must incorporate knowledge of virtue that teaches people about ethics and moral values; (2) local wisdom must teach people to love nature, not to destroy it; and (3) local wisdom must come from the older members of the community. They also explain that local wisdom is presented in many forms, through people's thoughts, occupations, ways of living, and social values[6].

Local wisdom contains the knowledge of virtue that educates people about values and ethics, loves the nature, and is inherited from the previous society. Local wisdom is presented in various forms, through thinking (what others think), the way of life, and the social values of society.

One form of local wisdom in Minangkabau (West Sumatra) is Minang song. Minang song has two main elements, namely elements of music and lyrics. First, the musical elements Minang songs have Minangkabau uniqueness. Minang songs have a variety of unique Minang musical instruments, such as talempong, gandang, bansi, saluang, rabab, and kecapi. As a pop genre, Minang music experiences acculturation with modern music, so its musical instrument is a fusion of modern musical instruments, such as keyboard, electric guitar, saxophone, trumpet. The rhythm and melodies of Minang songs have a unique feel, which has a Minang (gariniak) curve. Minang songs are delivered in a strains melody with the uniqueness of "gariniak"[7].

Second, the lyrics of Minang songs have the form of poems and rhymes. Pantun once played an important role in Minangkabau art. Minang people often express their feelings with rhymes, dialogue, even the berbalas pantun. Formerly the rhyme is very understandable and lived by Minang people, including young people, adults to parents, both men and women[8]. The power of Minang songs lies in the values contained in the song lyrics that reflect the Minangkabau costum values. The lyrics give an indication that "Pusako urang Minang tu, iyolah kato" means the heirloom of the Minang people is a word. "Kato bakieh (satirical word), katobamukasuik (word intended for ...), tanyo ba alamat (a clear question), mangado manghadang tampuak (things that are right on target), balaia manghadang pulau (attempt to complete adventure)". Each word has a specific mean and purpose. In addition, the lyrics of Minang songs have polite and guiding wisdom values.

These values are very important to be actualized in the process of education and learning in schools towards the development of the character of learners. Education as a cultural process is not only a process of knowledge transformation focused on the mastery of intellectual ability alone, but also plays a role in passing positive values of culture and local wisdom as a guide in giving birth to actions and behavior. Education should strive to make Minangkabau adat educational values and Minang songs as a guide for childbearing behavior and behavior of learners. These cultural efforts can serve as a means to foster and build the character of learners[9].

Reality that occurred in the field leaves some problems that are visible from teachers and early childhood factors. First, teachers are less able to provide lessons related to local area songs. Even if it is done, just memorize the song without continuing with the process of exploration of meaning and internalize the values of local wisdom contained in the song. Second, early childhood. Many early childhood who do not know the song of their own region, in addition to learning that tends to memorize without knowing the meaning and values of local wisdom resulted in the early childhood ignorance of the importance of local wisdom values contained in Minang songs, so the child early age will have difficulty in interacting with their own cultural society, and eventually the character weakens. This condition leads to the emergence of behavior that is not characterized, civilized, and cultured, such as early childhood that does not respect the parents, peers, and society.

The problem is exacerbated again with the rapid pace of development of science and technology and globalization that hit the whole line of life. The entry of external cultures will automatically affect the local culture. The values of local wisdom begin to be abandoned by its own cultural followers, will certainly have an impact on the loss of Minangkabau culture.

Given the importance and strong influence of music art (Minang song) in cultivating the values of local Minangkabau wisdom and help strengthen the character of early childhood, should be given experience singing that can bring closer and stimulate early childhood to the arts and culture of his own region. In other words, early childhood needs to know and internalize songs that reflect the values of his own local wisdom. The musical activity helps the achievement of Minangkabau community goals are to form noble individuals, cultured human beings, and civilized human beings[10].

\section{RESEARCH METHODS}

This research uses two methods. First, hermeneutic method. The hermeneutic method is performed to reveal the values of local wisdom contained in the song and refers to the elements and application of a multidisciplinary hermeneutic analysis. Ricoeur's opinion that elements and application of hermeneutic theory, namely 1) the objectification of the structure of the text, 2) the distortion, 3) the appropriation, and 4) the analogy of the game. Second, ethnographic methods[11]. Ethnographic methods are used to view and photograph the process of internalizing the values of local wisdom by early childhood in school. Ethnography is a qualitative research design. Researchers describe and interpret 
patterns of sharing and learning the values, behaviors, beliefs, and languages of cultural-shared groups, both as processes and research results. Ethnography involves expanding observations of groups through participant observation, researchers directly involved in daily life of school and family/community, observing and interviewing groups of participants. The ethnographer learns the meaning of cultureshared behavior, language, and interaction[12].

\section{RESULTS AND DISCUSSION}

\section{A. Local Wisdom Values in the Minang Song}

Kampuang Nan Jauah di Mato song was created by Aminos and popularized by OslanHusein. He is well known as an Indonesian singer and actor with the name of his artist Oslan. In the era of the 1950s famous as a singer who developed Minang songs, among the songs that were sung Oslan is very popular is Kampuang Nan Jauah di Mato song.

Broadly speaking, Kampuang Nan Jauah di Mato song tell and illustrate the values of love and longing among the younger generation (rang mudo) Minangkabau born, playing, growing, playing music together, and socializing with each other in kampuanghalaman (Minang realm) whose geographical conditions are covered by many mountains. Viewed from the aspect of lyrics the song has meaning, as follows:

\section{First Stanza}

Kampuang Nan Jauah di Mato song consists of three and four song sentences. The first sentence states, "Kampuang nan jauah di mato". Lexically, the sentence can be interpreted as an expression of the love of Minang people who are in the monitoring or outside the realm of Minang. Kampung or ranah defined as as a place of birth, grow, and development of Minang society. Kampung or Minang realm, geographically located in the hillside area.

The love of the people of Minangkabau to the hometown surrounded by mountains or in the hillside area also raises a high sense of longing for friends or relatives as a child who always accompany the daily life of children or young generation Minang, as stated in the lyrics of the song, "Den takanajojokawan-kawan lamo, sangkek basuliang-suliang". The word basuliang-suliang contains many meanings, in writing/literally meaning to play the flute together while implicitly or the meaning of a word or other meaning expressing the atmosphere of playing together, sharing together, and the activity or atmosphere is often done.

\section{Second Stanza}

The second verse of the song consists of four sentences of the song which means that the inhabitants or citizens who inhabit the realm of Minang contains the beautiful people. The meaning is expressed by the lyrics, "Panduduaknyo nan elok, nansuko bagotong-royong". The meaning of the word "elok/beautiful" means lexically as friendly, courteous, peaceful, and tolerant among the fellow citizens or citizens who inhabit the Minang realm, whether the relations between
Minang people and minang relations with other people of different religions and different cultures.

Friendly attitude, courtesy, peace, and a high tolerance to be a powerful tool to build Minangkabau region and will be realized with the activities of mutual cooperation. Collective gotongroyong activities contain psychological consequences to bear the pain and pleasure. Pain and pleasure is not a constraint, but it becomes a motivation for all residents or residents Minang realm to solve problems with all the risks together. The condition is often referred to as the cooperation of citizens. This is stated in the lyrics that say, "Sakiksanangsamo-samodiraso".

The atmosphere of hospitality, courtesy, peace, and tolerance gave birth together (gotongroyong) is always remembered and proud by residents or residents of Minang. The atmosphere is a barometer and a guide for Minang migrants to live their lives in the rantau or in the country people. As stated in the lyrics, "Den takanajokampuang".

\section{Third Stanza}

The memories of the past that the Minangkabau society passes from small to adulthood, both geographical conditions, as well as the friendly atmosphere, courtesy, tolerance, and togetherness that is formed in the realm of bundo or kampuanghalaman (village) psychologically raises the feeling to always remember and remember the time- that period, let alone the longing for the family (mother, father, and brother or sister).

The condition always overshadows the Minang people to quickly return to Minangkabau's hometown, as stated in the lyrics, "Takanajokampuang, induak, ayah, adiaksadonyo. Rasomaimbaudenpulang. Den takanajokampuang". Overall the lyrics of Kampuang nan Jauah di Mato songs describe the peaceful, comfortable, peaceful, and beautiful hometown atmosphere as well as having friendly, courteous, tolerant, and cooperative attitude (mutual cooperation) influencing mindset and belief Minangkabau people and always motivate the Minangkabau people to always love, see, and remember the hometown where they are.

The actions, behavior, and thoughts of Minang people depicted in the lyrics of the songs are the values that provide guidance to bear cultural attitudes and character. These values convey the knowledge and advice that should be recognized, followed, practiced, and cultured by Minang people. In other words, these values are educational in order that Minang people can live safe, prosperous, happy in the world and the hereafter.

Based on the explanation of the hermeneutic analysis above, it can be identified some of the educational values contained in the lyrics of Kampuang nan Jauah song in Mato, namely: 1) love and miss the village (Minang realm), 2) peace and justice, 3) polite, 4) tolerant, and 5) togetherness (goton groyong). These values are believed and serve as one of the sources or guidelines to educate Minang people to always create a safe, peaceful, and safe life in the world and the hereafter. 


\section{B. Internalization of Local Wisdom Values}

The learning process undertaken in Early Childhood Education outlines that the values of local wisdom contained in Kampuangnan Jauah di Mato are done through several stages:

\section{Song Appreciation Process}

By definition, appreciation can mean someone's activity in assessing or appreciating artwork. Steps in appreciation are often done with observation, enjoyment, appreciation, and judgment. In the process of appreciation depicted in writing leads to observation, enjoyment, and appreciation of Kampuang nan Jauah di Mato song. After observing the learning process of the song Minang. Early child appreciate Kampuang nan Jauah di Mato song by observing song. How to observe the teacher by playing the song through the media Video Compact Disk (VCD), so that young children can see and listen to the song carefully.

\section{The Imitating Song Process}

After viewing and listening to songs through VCDs, with the help of early childhood teachers do the exercises mimicking songs in bits and pieces. The teacher guides the practice of mimicking the song in two ways: singing per song sentence and per song verse. Exercises per repetitive pieces are repeated, until the child can sing the song correctly and correctly. In order for the process to mimic the song can be done correctly and correctly, the teacher uses a musical instrument, such as a keyboard to accompany the singing exercises, so that the sound issued by children in tune with musical instruments.

\section{Song Expression Process.}

After the process of imitating the song, proceed with the process of expressing themselves through the song. In addition to singing with the precision of rhythm and tone, the teacher guides early childhood to sing the song with full of inspiration. In keeping with the kind of tempo of Kampuang nan Jauah di Mato song that is joyful and joyous, the children sing with eager attitude. Children are given the opportunity to express songs together.

The process of Identification and Understanding the Meaning of Song Lyrics

After completing the performance of expressing the song with joy and happiness, the teacher did a question about the content or message contained on the song. The content or message contained in the song can be said as the values of local wisdom. The values of local wisdom are: 1) love and miss the village (Minang realm), 2) peace and justice, 3) courtesy, 4) tolerance, and 5) togetherness (gotong royong). These values are believed and serve as one of the sources or guidelines to educate Minang people to always create a safe, peaceful, and safe life in the world and the hereafter.
The values of local wisdom that the learners have identified and understood are implemented and implemented by the child, whether they are at school or at home, so that they can be properly internalized. Here illustrated, the process of internalizing the values of local wisdom contained in the song Kampuang nan Jauah di Mato song:

First, the love of the Minang realm is shown by using Minang language when talking to friends and describing feelings of pleasure when looking at typical Minangkabau buildings (Rumah Gadang, Rangkiang, and Carano). Second, peace and justice are shown by being willing to be friends with anyone without discrimination. Thirdly, courtesy is shown with kindness to everyone. Fourth, tolerance is shown by mutual respect for human beings. Fifth, gotong-royong is shown with a willingness to work together to clean up the environment, working together to maintain the cleanliness of class and school.

\section{References}

[1] S.S. Sinaga. "Pemanfaatan dan Pengembangan Lagu Anak-anak dalam Pembelajaran Tematik pada Pendidikan Anak Usia Dini/TK”. 2010. Online https://journal.unnes.ac.id/nju/index.php/harmonia/article/view/55/54 diakses tanggal 04/10/2017

[2] K.H. Dewantara. (1977). Pendidikan: Bagian I. Yogyakarta: Majelis Luhur Persatuan Taman Siswa.

[3] Djohan. Psikologimusik. Cetakanketiga: Edisirevisi. Yogyakarta: Galang Press, 2009

[4] K.S. Astuti. Shaping morality through music learning in formal schools in Indonesia: An evaluation study. Artikel dipublikasikan pada Asia Pasific Network for Moral Education 5th dalam Annual Conference Interdisciplinary Moral Education in Asia's Globalising Societies; Concept and Practices. Japan: Nagasaki University, June 2010

[5] K. Swanwick. A basic for music education. Rouledge: Taylor \& Francis GroupM. Young, The Technical Writer's Handbook. Mill Valley, CA: University Science, 1989.

[6] K. Kongprasertamorn. "Local wisdom, Environmental Protection and Continuity Development: The Clam Farmers in Tambon Bangkhunsal, Phetchaburi Province, Thailand". Manusya; Journal of Humanities 10.1, 2007

[7] S. Budiman. Lagu Minang Baru Muncul di Era 70-an. Padang: HarianHaluan Padang, 2011

[8] Darwis. Tafsir pantun Minang I. Artikel 655. Diambil pada tanggal 22 Januari 2012, online http://www.cimbuak.net/content/view/655/5/1/1, November 2005

[9] Desyandri. "Nilai-nilai Edukatif Lagu-lagu Minang untuk Membangun Karakter Peserta Didik". Jurnal Pembangunan Pendidikan; Fondasi dan Aplikasi, Vol. , No. 2, halaman 126-141, 2015

[10] Amir M.S. Adat Minangkabau: Pola hidup dan tujuan hidup orang Minang. Jakarta: Citra Harta Prima, 2011.

[11] W. Fithri. Mau kemana Minangkabau? Analisis hermeneutika atas perdebatan Islam dan adat Minangkabau. Yogyakarta: Gre Publishing, 2013

[12] J.W. Creswell. Qualitative inquiry \& research design: Choosing among five approaches. Second edition. Thousand Oaks, London, New Delhi: Sage Publications, 2007

Implementation Process of Local Wisdom Values 